\title{
THE INFLUENCE OF IDEOLOGIES ON CHINESE MANAGEMENT CHARACTERISTICS AND ITS RELEVANCE IN CROSS-CULTURAL MANAGEMENT BETWEEN CHINA AND THE EUROPEAN UNION
}

\author{
A CONCEPTUAL PAPER
}

In this paper, the authors give an introduction to the four most important ideologies impacting culture and the way of thinking in China today, i.e. Confucianism, Daoism, Legalism and Buddhism.

First, the authors provide an overview of the historical period where these ideologies originate from, and explain how their concepts were interpreted by the social elite. In the next chapters, they examine each of the ideologies separately. Confucianism is the best known Chinese ideology worldwide, in relation with business it is mostly dealing with questions of business ethics, while Daoism addresses behavioral questions and Legalism examines the methods of leadership from a rather totalitarian point of view, all of them specifically related to Chinese management. Buddhist economics deals with comprehensive economic questions, but it can be used for developing more sustainable management practices.

Although the authors examine their current impact on management in China, this paper logically paves the way for further research areas such as the impact of Buddhist economics on Chinese management, or the correlation between the embeddedness of these ideologies and a leader's preferred managerial role or management style.

Keywords: Chinese management characteristics, cross-cultural management, Confucianism, Daoism, Legalism, Buddhism

$\mathrm{T}$ he examination of ideologies in researches related to Chinese management is usually conducted from a historical perspective. This paper aims to pave the way for a broader research overcoming the historical perception and linking the ideological influences on Chinese managerial behavior with cross-cultural management concepts to support the economic cooperation of the People's Republic of China and the European Union.

Chinese $^{1}$ capital has an increasing importance in Hungary and in the other countries of the European Union (see Figure 1 and 2.): the overall value of the imported products from China to the EU (Eurostat, 2018), as well as the amount of foreign direct investment from China to Hungary (KSH, 2018) has almost doubled during the past ten years, while the exports of the EU to China are triple of the 2016 amount. With the Belt and Road initiative ${ }^{2}$, Chinese influence is expected to grow exponentially. Chinese firms are becoming strategic partners of Hungary with large-scale investments targeting the country. The growing number of Chinese organizations inevitably results in increasing interactions between the people of China and Europe. Chinese leaders and managers take part

1 In this paper, when addressing contemporary issues of China, we always refer to the political unit of the People's Republic of China, excluding the special administrative regions of Hong Kong and Macau as well as the Republic of China (Taiwan).

2 The Belt and Road initiative was prompted by President Xi Jinping in 2013 in an attempt to emphasize the openness of the Chinese economy and to support its integration with the development of the world economy. (Chan S. , 2017) Du and Zhang (2018) found, that after the 2013 announcement of the initiative, Chinese firms became more willing to engage in mergers and acquisitions, with Western Europe being one of the main destinations of investments in both infrastructure and non-infrastructure sectors ( $\mathrm{Du}-\mathrm{Zhang}, 2018)$. in cross-cultural preparation trainings to get acquainted with the European culture, business practices and other cultural differences, but it is equally important for us to have a basic knowledge of the Chinese business culture to make the cooperation more effective. Since each organization has its unique way on responding to internal and external challenges, considering the characteristics of the other culture and attempting to adapt to it can be crucial for managers engaged in multinational activities (Fekete Dimény, 2012).

Figure 1.

The amount of export and import products between the PRC and the EU, 2006-2017

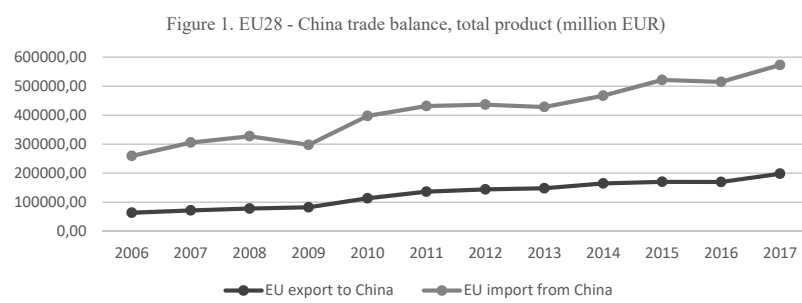

Source of data: Eurostat

As the Chinese and European approach to business and management is inherently different, the understanding of the Chinese way starts from the historical and ideological background of the country. Considering this, the aim of this paper is to provide a basic insight to the most influential ideologies of China. 
Figure 2. The amount of Chinese foreign direct investment in Hungary, 2006-2016

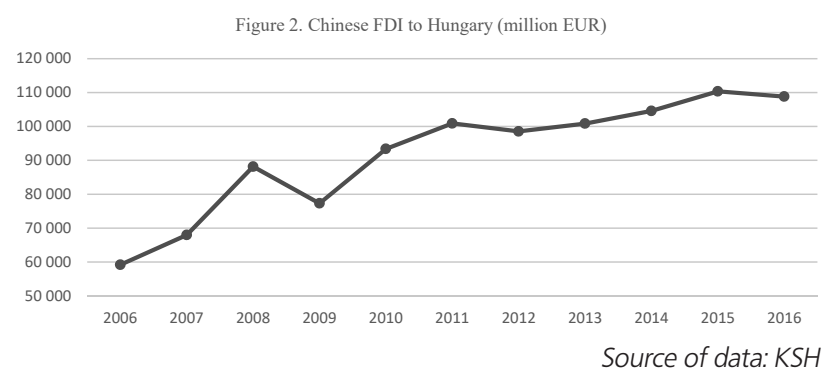

For the better understanding of the concepts, it is important to be familiar with the historical periods each ideology comes from. Historically, Confucianism and Daoism originate from a socially and politically transforming country, while Legalism can be traced back to an era of wars (Salát, 2009). This historical background defines the ideologies, while all three of them aim to solve the problem of their respective historical era, Confucianism and Daoism emphasize the importance of virtues and depict the qualities of an ideal leader (Gilbert, 2002) (Xu, 2009), Legalism is more pragmatic, as it attempts to give specific, practical advice on how to defeat the enemy and remain in power $(\mathrm{Fu}$, 1996). Buddhism is the most important ideology of foreign origin in China, missionaries from India used land (different paths of the Silk Road) and maritime (from the Western coast of India towards Canton) pathways to reach China. The time of the first appearance of Buddhism in China is dated around the beginning of the $1^{\text {st }}$ century, which was an era of revival, social, political and economic prosperity (Hamar, 2004).

The historical introduction is followed by the description of each ideology, their main concepts, theorists, the context and the social group the ideologies can be best applied to - which also highlights its contemporary relevance and possibilities for the fields of further research.

To see the economic significance of these theories, we are going to review the works of contemporary researchers who examine the relation between the concepts, or certain parts of the concepts, and today's management theories and practices.

\section{Historical background}

This chapter provides an overview of the historical situation in which the ideologies to be discussed were conceived: it is important to note, that all of the ideologies were born during a relatively unstable era after a long time of social and political stability. The most common characteristics of Chinese management (such as centralized control, collectivism, harmony, paternalistic leadership, flexible strategies, family businesses, strong organizational networks and the importance of business connections) can be traced back to the early thinkers and ideologists of China (Rarick, 2009) before and during the early years of the country's first unification.
The first centuries of Chinese history are only documented based on transliterations of ancient myths, for the existence of which there are no evidences, but as tradition they are an important factor for the country, and still have great importance in Chinese philosophy. The legends include mythical figures such as the Yellow Emperor (Huangdi 黄帝), who is believed to have invented some important tools (for example the axe, the mortar or well drilling), or Fuxi 伏羲, who taught people to hunt, to fish and to cook meat. One of the last heroes of the period were Yao 尧 and Shun 舜, who were the archetypes of the Confucian 'superior man'. The first dynasty proven to have existed was the Shang dynasty 商 $\left(18^{\text {th }}-11^{\text {th }}\right.$ century BC) (Fung, 1997). The aristocratic social structure was formed during these times, the destabilization and transformation of which, at the end of the Zhou dynasty 周 (1046-221 BC), provided the basis for the formation of the most important ideologies. While the first roots of Confucianism ${ }^{3}$ date back to a historical period of social stability (the Western Zhou 西周 period, 1046-771 BC), and the development of the Confucian philosophy and Daoism started in an era of social transformation and economic prosperity (Chunqiu 春秋, 722-481 BC), the first representatives of Legalism lived in an era of wars, social and political unrest with the main purpose of the economy being to serve the military (The Warring States 战国 403-221BC) (Salát, 2013).

After the Warring States period, the country was unified by the Qin dynasty 秦 (221-206 BC) and Qin Shi Huangdi became the first emperor of China. He governed the country based on rigorous Legalist principles and strict regulations which resulted in his great unpopularity, therefore, shortly after his early death in $206 \mathrm{BC}$, the Qin dynasty has fallen. To avoid a similar fate, the first emperor of the succeeding Han dynasty started the consolidation of his predecessor's legacy with the easing of regulations and tax burdens. The power of the central administration remained weak, but the country started to regain its strength and political, social and economic stability. This was the time where the first written evidences of Buddhism originate from, and starting from this period, the first religion and ideological school of foreign origin started to gain reputation and popularity in China (Fitzgerald, 1989).

\section{Confucianism}

\section{Historical background}

The name, which most of the Western world uses to address this ideology, originates from the $16^{\text {th }}$ century, when Jesuit missionaries Latinized the name of the founder of the philosophical school (Kongzi 孔子 or Kongfuzi 孔夫 子). In China, however, it is called $r u$ 儒 (or rujia 儒家), originally referring to a certain group of literates. Only later, when Confucianism (or Rusim) was recognized as a prominent school, has this ideology become identified with Confucius and his disciples. Confucius and his disci-

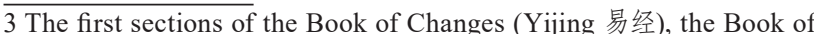
History (Shujing 书经) and the Book of Songs (Shijing 诗经) originate from the Western Zhou period.
} 
ples belonged to the social group of $r u$ (mentioned earlier in this paragraph), whose occupation was the studying and teaching of the "six classics" (Book of Poetry, Book of History, Book of Rites, Book of Music, Book of Changes and the Spring and Autumn Annals) (Yao, 2000). The teachings of Confucius are the foundations of the Confucian school, however, they were not created by him, his teachings were based on lessons he draw from Chinese history. Therefore, Confucius is regarded as interpreting, preserving and mediating the ancient heritage of China and, together with his disciples and followers, synthetizing it into a system of principles, virtues and ideologies suitable for different aspects of life, society and politics (Hofstede - Bond, 1988).

As in the background of Confucian teachings was an intention to contribute to the consolidation and to the restructuring of social and political circumstances, it can not only be regarded as an ideology of human life, but it is also an important theory of power and authority. The first unification of China was achieved based on legalist principles, and in this era (Qin Dynasty 秦, 221-206 BC) Confucianism was suppressed. Confucianism started to gain reputation again during the ruling of a Han Dynasty 漢 emperor, Dong Zhongshu (191-115 BC), and gradually, it became the official ideology of the country. The Taixue 太学, or the Imperial Academy was established 124 BC, which served as the educational institution for prospective government officials and bureaucrats (Salát, 2009).

\section{Modern implications}

Warner (2010), seeking the conception of Confucian HRM, finds, that with China being the first country to base its bureaucracy on education instead of bloodlines, with a solid Confucian foundation of civil service enduring through different historical circumstances and rulers, contributed greatly to the theory and practice of not only Chinese, but also to the Western management and bureaucracy (Warner, 2010). Until its abolition in 1905, the Confucian Four Books and Five Classics served as the basis of scholar official classes and the imperial exams of the examination system, which meant that those aspiring for highest ranking offices had to study these works in great detail (Csikszentmihalyi, 2005).

The most important principles of Confucianism are about preserving traditions, possessing good human qualities and adhere to the rules of social hierarchy (Fitzgerald, 1989). The ideal person, which everybody, especially leaders should strive to be, is called junzi 君子, or 'superior man'. The Confucian concept of junzi, or superior man is described as follows: "Is it not a pleasure, having learned something, to try it out at due intervals? Is it not a joy to have like-mind friends come from afar? Is it not gentlemanly not to take offence when others fail to appreciate your abilities?" (The Analects, I/1, cited by Lin and Ho, 2009). This idea is able to support the cooperation of people from different cultures working together in multinational corporations and provides a solid foundation for harmonious relations among the members of a diverse community on the long-term (Lin - Ho, 2009).
Hofstede and Bond (1988) pointed out, that beside the three cultural dimension applying to both East and West (Power Distance, Individualism/Collectivism, Masculinity/Femininity), there are two dimensions which are unique to the East and West respectively: Uncertainty Avoidance and Confucian Dynamism. The latter consists of values rooted in the teachings of Confucius: searching for Virtue, as opposed to seeking the absolute Truth in uncertainty-avoiding cultures. (Hofstede \& Bond, 1988) These virtues are the necessities for one to become a junzi: ren (仁, benevolence, humaneness); yi (义, righteousness); li (礼, proper rite); zhi (智, knowledge); xin (信, integrity). Ren, or benevolence is the most important among them, and it can be associated with several qualities an ideal person has to hold, such as caring, perseverance, self-restraint or modesty. Chan (2008) attempts to define the relationship between business ethics and profit making in the Confucian value system. He notes, that even though in some cases profit making in Confucian works is associated with inferior personality or a ruining effect on the county, they don't completely disparage business activity. Confucian thinkers argue that one should strive for human virtues (benevolence, righteousness, humanity, development of personality) instead of their wealth. However, this should not be interpreted as a necessity for complete cease of business activities, it rather suggests that one should find the balance in striving for profit and human virtue. The social harmony is a result of respecting social hierarchy which, according to the Confucian teaching, consists of five relationships and is described by ten morals (Kósa, 2013). Two of these relationships are inside the family, while the remaining are related to society, and all of them describe connections between superiors and subordinates: father's endearment, son's filial devotion, elder brother's gentleness, younger brother's respect, husband's fidelity, wife's compliance, senior's benevolence, youth's submission, ruler's kindness, and subordinate's loyalty (Child Warner, 2003). As Hill (2006) argues, the key Confucian principles have significant impact on Chinese leadership style, interpersonal relations and individual values. The paternalistic leadership style and the regarding of the corporation as family, as well as the preservation of hierarchy and avoiding self-interest can all be traced back to the principle of $l i$ and to the rigid system of connections (Hill, 2006). The roots of the paternalistic leadership, which is a hierarchical leadership method common in overseas and mainland Chinese family businesses, are in the traditional Chinese family structure, which is also defined by classical Confucian values. The father - son relationship is extended to superior - subordinate relationships of the company, where the superior has to guide, protect and care to the subordinate, who, in return is expected to be loyal and deferential (Farh - Liang - Chou - Cheng, 2008).

Chan (2008) argues that Confucian values and business ethics puts greater emphasis on hierarchy, guanxi and social harmony. The practice of guanxi (interpersonal relationships or connections) is based on the Confucian principles of reciprocity and interdependence and involves mutually beneficial social interactions (Chan G. K., 2008). 
Harmony in a company refers to every participant knowing their place and role while complying with order and practicing benevolence towards each other (Wang - Chee, 2011). The outcome of the research of Wong et al. (2010) also supports the idea that hierarchy and the role of guanxi between subordinates and supervisors has an outstanding importance in Chinese management (Wong - Wong - Wong, 2010).

Wood and Lamond (2011) examine the presence of Confucian values in business ethics and how to reach self-regulation through them. They conclude, that business leaders in China today still consider being a junzi as the standard of personal integrity, which can be achieved by developing self-regulation. The Confucian practices to achieve this include rites and ritual, music, self-examination and mentoring. The virtue of rite (li) and rituals of the organization can help define the communication between people and strengthen their loyalty and integrity to the organization. Music can play a role in building unity (e.g. by starting the day with a song together) or developing interpersonal relationships among business partners or colleges (e.g. karaoke singing). The Confucian practice of self-examination includes one's reflection and consideration of everyday events, behavior and attitudes which is also an important educational practice of developing ethical managerial skills. Employee orientation, education and career development would not be a sufficient way of mentoring in an organization, according to Confucius. It should rather include encouraging active discussions, with offering encouragement and corrections to the opinions of the participants (Wood - Lamond, 2011). A prerequisite to benevolent leadership is also the self-cultivation, and if one possesses this ability, they will be able to shape and to lead others (Yang - Peng - Lee, 2008).

\section{Daoism}

It is important to note, as the two concepts may differ from each other, that when describing Daoism in this paper we always refer to the Daoist philosophy, as opposed to religious Daoism.

\section{Historical background}

Traditionally, the author of the most important work of Daoism, the Daodejing 道德经 (Classic of the Way and Virtue), is Laozi, however, there is no clear evidence supporting this, and it is widely accepted that the Daodejing, which is also called Laozi, is a collection of works of several different authors. Laozi was working in the Archives of the imperial court during the Zhou dynasty, but seeing the power of the dynasty decline made him leave the court. According to the tradition, during his journey he wrote down his thoughts about dao 道 (lit. 'way') and de 德 ('virtue') when he met a guard at the border who asked him to leave his wisdom for them before he leaves. After leaving, there is nothing known about him (Kósa, 2013).

The Daodejing, and the teachings of Daoism are interpreted in multiple ways. An important interpretation is that it was intended for the ruling class of the late Zhou pe- riod to offer suggestions for the moral and political problems of the era. In this regard, Daoism disagrees with and criticizes Confucianism, claiming that is not effective in solving the problems of society, moreover, the Confucian suggestions are harmful for the already disorganized social order. (Chan A. K., 2000) Also to the contrary of the proactivity of Confucianism, Daoism emphasizes wu wei, or non-action, and does not support hierarchy as much as Confucianism (Warner, 2010).

During the Qin dynasty (221-206 BC), both Confucianism and Daoism were prohibited to teach or to study. The revival of Daoism started only during the late Han dynasty, when the religious Daoism has also emerged. Parallel to Confucianism becoming an official state ideology, Laozi became the founder of a new religion, which, however, had little in common with Daoist philosophy (Fung, 1997).

The most important principle of Daoism is the dao 道 (the Way) itself. It refers to a natural, universal way of life, the way everything should be and the natural rules that control the universe, such as the change of seasons. It is also associated with the pursuit of the perfect order, where every controversy (such as life and death) can be resolved, and for which the sage should strive (e.g. yin 阴and yang 阳). Even though the dao has overcome the concept of yin and yang, it is still somewhat closer to the yin, or female principle, which is characterized by softness, femininity and water-like qualities. An important quality of the sage ruler is the $w u$-wei, or non-doing, which means that the ruler identifies himself with the dao and instead of pursuing his own goals, allows the dao to be manifested through him (Kósa, 2013).

\section{Modern implications}

An effective way of adapting Daoism to leadership is the water-metaphor. According to Laozi, the best human qualities are similar to that of water, so every people, especially leaders, have to pursue these water-like qualities, namely altruism, modesty, flexibility, transparency or honesty, and persistency. The leadership style of people should be also similar to water - gentle but persistent. When striving to achieve a goal, leaders should bear in mind how water is very soft, yet it can attack and form hard things due to its power and persistency (Lee - Han - Byron - Fan, 2008).

As it can also be seen from the above, according to Laozi, the Daoist leader is invisible (Helle, 2017). He should understand and predict the environment and help the organization adapt to it and maintain harmony. According to the findings of Jung et al (2010), the invisible leadership style is the less risk-taking, the less communicating, the less likely to articulate vision or monitor operations, relatively unlikely of authoritative behavior, but also not showing as much benevolence as the other leadership styles examined in the study (advanced, authoritative, progressing) (Jung - Chan - Chen - Chow, 2010). The importance of the concepts of the invisible leadership in modern Chinese organizations is also supported by the study of Wong et al. (2010), who find, that the trust of workers towards the management and towards the organization can- 
not be clearly distinguished, as they conceive these two entities very similar (Wong - Wong - Wong, 2010).

The other important aspect of Daoism is the concept of de 德, which refers to a humanistic behavior, a character of virtue. According to Daoist principles, humans should be humble and modest, and shouldn't have too many desires because those who have desires, are not content, they don't know where their boundaries are. These might seem, to a certain extent, similar to Confucianism. However, Laozi has despised on Confucian values of humanity and righteousness, because these virtues mean that one has lost dao and de, where dao is superior.

Harmony, the balance of yin and yang is an essential part of Daoism, it should be priority for leaders to preserve this for the organization to be successful. Yin can be understood as the receptive, structural part of the organization while yang is the active, creative, functional part (Durlabhji, 2004). According to Wang and Chee (2011), the Daoist organization should be decentralized, with great autonomy to its departments and little interactions between them. The long-term policy is unchanged and aims to provide comfortable living for itself and its people, it maintains little communication towards outsiders and has a low public profile (Wang - Chee, 2011).

\section{Legalism}

\section{Historical background}

Legalism is both similar to and different from the other ideologies. It is similar, because its goal is to solve the social and political problems of its era, but it is also different, because instead of looking for experiences of the past, it believes that for the unprecedented problems, new, radical solutions are required. After the fall of the Zhou Dynasty, wars between the states became more and more frequent, which required a solid administrative background with the concentration of power to deal with the increasingly complex tasks. Governors started to implement the practical and effective ideas and were looking for people supporting them with such suggestions (Fung, 1997).

Legalism is also different from Daoism or Confucianism because it is not an organized philosophical school, there were no masters, teachers and disciples. Legalism is a term given by succeeding generations to a certain group of people, thinkers, advisors, who were engaged in similar activities and were dealing with related problems based on similar values. It was Han Fei who can be considered the founder of the school, he attempted to collect and improve the teachings of his predecessors according to his system. It is due to his work, that the works of numerous Legalist thinkers were preserved. At first glance, one could think that Legalism has no roots in Chinese history and cultural tradition, and after it supported the unification of China and the emergence of the Qin Dynasty (221-206 BC), it disappeared completely. In fact, there were several statesmen during the Chunqiu period (722-481 BC), who can be regarded as the forerunners of Legalism because of their pragmatic regulations, and, after the fall of Qin Dynasty, during the early years of Han Dynasty, Legalism contin- ued to exist as an independent school, before its integration into Confucianism and becoming an important part of state ideology (Salát, 2013).

Because Legalism originates from a period of social and political instability and frequent battles between the concurring states, its principles are also different from those of other Chinese ideologies, they seek practical answer for the most urgent problem of the period: how to deal with the changing social structures and how to defeat the other states in order to rule the whole country. Basically, it attempts to give specific guidance on matters of leadership and organization methods, but from a totalitarian point of view (Fung, 1997). One common feature of the Legalist thinkers was the aim of their work: to defeat other states and to stabilize the position of the governor. From this aspect, Legalist principles are the exact opposite of Confucianism, Daoism or Buddhism. If war, punishment or betrayal serves the purpose of the governor, then these are more than acceptable methods to use. Legalism is very rigorous and shows no mercy to anyone, it was the first concept which placed law equally above everybody (Fu, 1996). According to their idea, there is no difference between civils and nobles, relatives and strangers, law imposes the same verdict on everyone regardless of their social status. This perception is an important legacy of Legalism. Three famous Legalist thinkers, Shen Buhai, Shen Dao and Shang Yang were the first to emphasize the importance of the concepts of shu (tactics), shi (power) and $f a$ (rules or law). The three concepts were later synthetized by Han Fei. Obtaining and preserving power is one of the foundations of ruling, because it allows the ruler to impose his will on his subordinates, using different tactics. The ruler must use the power of law for the population, which imposes punishment on people harming the country and rewards them in case of being useful (Salát, 2013).

\section{Modern Implications}

Legalism was an important ideology behind China's ruling, but usually it was combined with Confucian values, especially in times of social and political order and prosperity. In periods of turmoil and unrest, Legalism appeared more frequently than Confucianism. The theory can also be applied to modern organizations. Most importantly, as opposed to Confucianism, Legalism builds on the basic thought of all human behaviors being driven by self-interest. According to this belief, an organization following Legalist principles should establish a profit-driven culture, make sure, that every employee's duties are clear and not overlapping with each other, the self-interest of people is satisfied by clear goals, and that every person, regardless of their position, is treated fairly and rationally (Wang - Chee, 2011).

In Legalism, or institutional theory (Wang - Chee, 2011), the position of a leader is defined by the three main concepts, shi (power or authority), fa (law) and shu (tactics). The first to obtain is power, once a leader has power, they can start using law and (management) techniques to govern subordinates. The basis of power is position (wei), however, according to Hanfei its rather considered as a 
prerequisite to power, but is not sufficient to maintain it, one must have talent and capability to achieve organizational goals, which also includes assigning capable people to key positions.

One of the tools to manipulate subordinates is $f a$, or rules and regulations. According to Hanfei these should be initiated by the leader, however, the origin of the law is supposed to be the $d a o$, as the fundamental principle and main driving force of the universe. The task of a good leader is using this to decide about right and wrong and establish the rules accordingly. This concept also underlines the importance of institutions in society and defines the relationship between people and the state, similar to the perception of homo-economicus or classical capitalism, where people are direct subordinates of the state without family ties or other subjective factors influencing the decision making (Sárvári, 2017). The other tool of the leader to manipulate its people and achieve organizational goals is shu, or management technique. This include the above mentioned assigning of capable people to key positions, as well as following the projects and controlling the results and evaluating contributions and granting rewards (Hwang, 2008). This perception of the single leader who directs his subordinates is a characteristic of individualistic societies, in collectivistic societies the common interpretation of the function of a leader is that he is solely responsible for any failures of the organization, but the successes of it are attributed to the whole collective (Dickson - Castano - Magomaeva - Den Hartog, 2012).

\section{Buddhism}

\section{Historical background}

Buddhism is one the most important religions in China, and as opposed to the ideologies addressed above, it stems from outside the country and it developed its basic principles independently from Chinese history before arriving to China (Tökei, 1996). During the first few hundred years of Buddhism in China, it received significant impacts from Chinese ideologies, mainly from Daoism. This is the reason why the terminology of Buddhism and Daoism is similar, for example they both use the concept of youwei (doing) and wuwei (non-doing). In fact, rather than claiming the values of Buddhism being misinterpreted in China, we can say that a Chinese "version" of Buddhism was created by synthetizing it with traditional Chinese ideologies (Chan W.-T., 1958). The Doctrine of the Mind and the School of Emptiness both had significant effect on the Chinese way of thinking. After the Doctrine of the Mind started to be suppressed, and from the merging of Daoism and the School of Emptiness, the Chan Buddhism came into being (Fung, 1997). As Chan Buddhism is the biggest school of the religion in China (Hamar, 2004) and the limitations of this paper do not allow to address the numerous other schools of Buddhism, in the following we always refer to Chan Buddhism.

According to the main principle of Buddhism, karma means the actions or deeds of the beings of the universe, which necessarily results in a consequence in the near or distant future. So, the life the individual is built from the succession of the karma (which is the cause of everything) and the impacts caused by the karma. This is not only interpreted to the life of people, but also to the whole universe, therefore, an action in the life of a sentient being can also result in causes in their subsequent life. This is the cycle of successive existence (Samsara), which is the basis of the sufferings of sentient beings. According to Buddhism, the suffering stems from the ignorance of people and their desire for and insisting to living, which makes them unable to quit the eternal cycle of births and rebirths. The liberation from this cycle means realizing nirvana (Fung, 1997).

\section{Modern implications}

Buddhist economics was first mentioned by Schumacher (1973) and it became a popular discipline since then. Its foundations are the values of Buddhism, and, as opposed to the homo-economicus, it describes the economic agents as (1) having only limited rationality, (2) being interdependent to each other and (3) aiming to minimize losses. The Buddhist approach distinguished two kinds of goods, those, which (1) satisfy human needs, and those, which (2) satisfy customer demand beyond basic human needs. The insisting or desire to consumption is considered as a cause of suffering, therefore Buddhism doesn't accept this consumption pattern and defines economic effectiveness as satisfying basic human needs with optimal use of resources (Kovács, 2016). The ethics of Buddhism is in synergy with the concepts of sustainability and responsibility, the study of Du et al. (2014) finds a positive effect of Buddhism on corporate environmental responsibility. The study of Nemcsicsné Zsóka (2006) also supports this idea, it found, that the environmental values an organization possesses also manifest themselves in the organizational culture, which (Nemcsicsné Zsóka, 2006), which suggests, that a corporation with Buddhist values could be more likely to implement a responsible environmental strategy.

The purpose of a Buddhist organization must be in line with the Buddhist idea of the meaning of life, therefore, every function of the organization (execution, communication, strategy, R-D etc.) need to a have a common goal of securing the spiritual development and harmony of the employees and stakeholders of the organization. This vision implies that materialism is only acceptable until it supports the functioning of the organization, the ethics followed by the organization and its people will not accept power-seeking or self-centered behavior, as these would have an isolating effect on the individual and an overall negative effect on the organization. Hence, managers and leaders of the Buddhist organization must had developed inner space and awareness towards their employees so that they can support the realization of the well-being and harmony of the people and the organization. They must reach a great quality of presence to be able to help the people with professional and personal struggles and to encourage them to work autonomously and constantly monitor themselves according to Buddhist values (Borden - Shek- 
hawat, 2010). According to Kovács (2014), implementing Buddhist elements in current management practices could be a feasible solution to today's global issues. The practice of meditation and improving mindfulness supports leaders in both adequate self-reflection and in being more effective in problem solving, decision making, avoiding mistakes and improving overall efficiency. By fostering compassion towards all sentient beings (i.e. the employees), the managerial body can transform into a group which supports sustainability on personal, organizational, social and environmental level without pursuing its own interest (Kovács, 2014).

Muyzenberg (2014) identifies three main concepts of Buddhism which can have an impact on organizational performance. The three laws of nature (1) underline that just like everything in the universe, organizations also depend on other organizations and external factors and they also have an influencing effect to the outside world (interdependence). Therefore, they should act accordingly and make the right choices considering how it affects others. Moreover, because everything has a cause and effects, and the effects will become causes of other things in the future, these form an endless chain in which each organization has to take responsibility for the changes caused by them. This is further emphasized by the law of impermanence, which points out that there is nothing which wouldn't change over time. For businesses, it is important to consider these factors while making decisions, it is essential to understand the causes of their situation and to assess the alternative solutions according to the desired effect. The concept of emptiness (2) refers to similar phenomena. In Buddhism emptiness can be translated as a universal interdependence of everything, which can be applied to sentient beings as well as organizations. For the latter it means, that they should not consider themselves independent, as it can lead to big problems if they don't recognize their dependence on human or natural resources. The dependent origination (3) refers to the 12 concepts of what happens in the mind: ignorance, mental formations, consciousness, mind-and-body, six senses, contact, sensation, craving, clinging, becoming, birth and decay-and-death. It is important to be conscious about these states of mind to avoid those leading to unethical actions (e.g. craving) (Muyzenberg, 2014).

\section{Summary and implications}

The most important Confucian values are respecting traditions and adhering to the rules of social hierarchy, and possessing the five virtues: ren ( 1 , , benevolence, humaneness); yi (义, righteousness); li (礼, proper rite); zhi (智, knowledge); xin (信, integrity). However, the theorists of Daoism place dao and de above the Confucian values of ren (humanity) and yi (righteousness). The Daoist qualities of altruism, modesty, flexibility, transparency or honesty and persistency can also be measured to determine the impact of ancient culture on managerial behavior.

The five relationships and their adequate behaviors (father's endearment, son's filial devotion, elder brother's gentleness, younger brother's respect, husband's fidelity, wife's compliance, senior's benevolence, youth's submission, ruler's kindliness, and subordinate's loyalty) can be extended to a corporate level to define the relations between leaders and subordinates. Another important aspect of business where Confucianism can be applied is business ethics, where Confucian values can show directions for leaders to become more effective by the five virtues, and to find balance between striving for profit and for human virtues.

Legalism attempts to give specific guidance on matters of leadership and organization methods with outstanding importance of law and regulations. Legalism was the ideology which formulated one of the most important and longest standing concepts of China, the superiority of law and its equal placement above everybody, regardless of social status. An organization following Legalist principles should establish in a profit-driven culture, make sure that every employee's duties are clear and not overlapping with each other, the self-interest of people is satisfied by clear goals, and that every person, regardless of their position, is treated fairly and rationally. A Legalist leader must consider the three main concepts: shi (power or authority), $f a$ (law) and shu (tactics).

The basic thought of Buddhism is that the suffering of sentient beings stems from the ignorance of people and their desire for and insisting to living, which makes them unable to quit the eternal cycle of births and rebirths, and that everyone should strive for having less desires to liberate themselves from this cycle and to reach nirvana. This principle is also an important part of Buddhist economics, which defines economic effectiveness as satisfying basic human needs with optimal use of resources and identifies desire to consumption, or insisting to consumption as a cause of suffering. A Buddhist organization needs to have a common goal of securing the spiritual development and harmony of the employees and stakeholders, and will not accept power-seeking or self-centered behavior. A Buddhist leader helps his people with professional and personal struggles, encourages them to work autonomously, and constantly monitors himself according to Buddhist values. Buddhism is also in synergy with the concepts of sustainability and responsibility, and implementing Buddhist elements in current management practices could also be a feasible solution to today's global issues, as studies have shown, Buddhism has a positive effect on corporate environmental responsibility.

According to cross-cultural management studies, the ability of cooperation of different cultures can be measured in different dimensions, such as individualism and collectivism (Ralston - Egri - Stewart - Terpstra - Yu, 1999) or avoiding and competing behavior in conflict management (Morris - Williams - Leung, 1998). To integrate the values of the ideologies and measure their impact on modern management, we assume that Confucian and Daoist values mostly influence the conflict avoiding behavior of the leader, while the impact of Legalist values is more detectable on the level of individualism and collectivism. 


\section{Conclusion}

The summary highlights that most of the ideologies address the ideal human behavior and the qualities of an ideal leader. Based on this result, we believe that the most relevant fields of business administration to associate the ideologies with are leadership and management theories, and in particular the theories of different leadership styles.

Among the Chinese ideologies, Confucianism seems to be the most, and Legalism the least researched topic in connection with Chinese management characteristics. In fact, since some concepts of Legalism gradually integrated into Confucianism, these two are often examined together. The presence of Daoism in Chinese leadership methods is the most difficult to examine, since, even though Daoism also addresses the qualities of an ideal person, its rather dealing with problems of wider perspective, such as the meaning of life or the way life should ideally be conducted.

Buddhism is different from the other ideologies in multiple aspects. First, its development cannot be associated with social and political changes in China which was the motivation for the development of the other philosophies. Its first appearance in China is also dated several centuries later than the foundation of the Chinese ideologies. However, due to its global reputation, in relation with economics, it is the most researched ideology among the ones addressed in this paper. We should note that researches on Buddhism and on Buddhist economics are not necessarily specific to China, so it is a possible area of further research to define the impact of Buddhism on Chinese management and leadership practices.

In consideration of the context of the work, the authors concluded that fruitful collaboration between European companies and the increasing number of Chinese managers in Europe (and in Hungary in particular) could be supported by more precise research data. These data should shed light on the correlation between management styles and/or managerial roles, and the deepness of a manager's knowledge on these ideological principles.

Therefore, we have defined the following directions to be basis of further research:

1. Examine the impact of the specific cultural characteristics of certain geographical sub regions of China on the interpretation of cultural heritage and its impact on management practices.

2. Examine the impact of the status of the decision maker on the involvement of their cultural beliefs and values during decision making - as Kazainé Ónodi (2010) pointed out, involving personal values into decision making is dependent on the status of the stakeholder (Kazainé Ónodi, 2010).

3. Determine the impact of policies of Mao Zedong and the creation of the PRC on the presence of classical ideologies in the modern Chinese mindset through a comparison with the Republic of China (Taiwan).

4. Establish the framework for a qualitative research on the leadership styles of Chinese managers engaged in cross-cultural management with the European Union after the assessment of the possibilities of integrating the four ideologies into a common influential system or dealing with them separately.

\section{References}

Borden, M. E. - Shekhawat, P. S. (2010): Buddhist practice and principles and their place in organizations. In: S. Nandram, - M. Borden (eds.) (2010): Spirituality and Business. Exploring possibilities for a new management paradigm. Berlin Heidelberg: Springer Verlag, p. 141-152.

Chan, A. K. (2000): The Daode jing and its tradition. In: L. Kohn (ed.) (2000): Daoism Handbook. Leiden: E. J. Brill, p.1-29.

Chan, G. K. (2008): The relevance and value of Confucianism in contemporary business ethics. Journal of Business Ethics, Vol 77. No. 3., p. 347-360. doi:10.1007/ s10551-007-9354-z

Chan, S. (2017): The belt and road initiative: Implications for China and East Asian economies. The Copenhagen Journal of Asian Studies, 35(2), p. 52-78. doi:10.22439/ cjas.v35i2.5446

Chan, W.-T. (1958): Transformation of Buddhism in China. Philosophy East and West, 7(3/4), p. 107-116. doi: $10.2307 / 1397344$

Chen, C.-C. - Lee, Y.-T. (2008): Introduction: The diversity and dynamism of Chinese philosophies on leadership. In: C.-C. Chen, - Y.-T. Lee (eds.) (2008): Leadership and Management in China: Philosophies, Theories, and Practices. Cambridge: Cambridge University Press, p.1-27.

Child, J. - Warner, M. (2003): Culture and Management in China. Cambridge: University of Cambridge, Judge Institute of Management, Working Paper. 03.

Csikszentmihalyi, M. (2005): Confucianism: An Overview. In: L. Jones (ed.) (2005): Encylopedia of Religions. Vol III. (2nd edition). New York: Thomson Gale, p. $1890-1905$.

Dickson, M. - Castano, N. - Magomaeva, A. - Den Hartog, D. N. (2012): Conceptualizing leadership across cultures. Journal of World Business, 47, p. 483-492. doi:10.1016/j.jwb.2012.01.002

Du, J. - Zhang, Y. (2018): Does One Belt One Road initiative promote Chinese overseas direct investment? China Economic Review, 47, p. 189-205. doi:10.1016/j. chieco.2017.05.010

Du, X. - Jian, W. - Zeng, Q. - Du, Y. (2014): Corporate environmental responsibility in polluting industries: Does religion matter? Journal of Business Ethics, 124(3), p. 485-507. doi:10.1007/s10551-013-1888-7.

Durlabhji, S. (2004): The Tao of organization behavior. Journal of Business Ethics, 52(4), p. 401-409.

Eurostat (2018): European Commission. Retrieved 04 21, 2018, from http://ec.europa.eu/eurostat/tgm/refreshTableAction.do? $\mathrm{tab}=$ table-plugin $=1-$ pcode $=$ tet 00035 language $=\mathrm{en}$ 
Farh, J.-l. - Liang, J. - Chou, L.-f. - Cheng, B.-c. (2008): Paternalistic leadership in Chinese organizations: research progress and future research directions. In: Y.-t. Lee, - C.-c. Chen (eds.) (2008): Leadership and Management in China: Philosophies, Theories, and Practices. Cambridge: Cambridge University Press, p. 171-205.. doi:10.1017/ CBO9780511753763.008

Fekete, H. -Dimény, E. (2012): Megfelelő kultúra=Kiváló teljesítmény? Vezetéstudomány, 18(4), p. 36-47.

Fitzgerald, P. (1989): Az ősi Kína. (A múlt születése). Budapest: Helikon

$F u$, Z. (1996): China's Legalists. The Earliest Totalitarians and their Art of Ruling. Armonk, London: M. E. Sharpe

Fung, Y.-l. (1997): A Short History of Chinese Philosophy. New York-London: The Free Press

Gilbert, R. (2002): Can Confucianism survive in an age of Universalism and Globalization? Pacific Affairs, 75(1), p. 11-37. doi:10.2307/4127239

Hamar, I. (2004): A kínai buddhizmus története . Budapest: Balassi Kiadó

Helle, H. J. (2017): Daoism: China's Native Religion. In: China: Promise or Threat? Leiden: Brill, p.71-81. doi:10.1163/j.ctt1w8h29s.12

Hill, J. S. (2006): Confucianism and the Art of Chinese Management. Journal of Asia Business Studies, 1(1), p. 1-9. doi:10.1108/15587890680001299

Hofstede, G. - Bond, M. H. (1988): The Confucius connection: From cultural roots to economic growth. Organizational Dynamics, 16(4), p. 5-21. doi:10.1016/00902616(88)90009-5

Hwang, K.-k. (2008): Leadership theory of Legalism and its function in Confucian society. In: C.-C. Chen - Y.T. Lee (eds.) (2008): Leadership and Management in China: Philosophies, Theories, and Practices. Cambridge: Cambridge University Press, p. 108-142.

Jung, D. - Chan, F. - Chen, G. - Chow, C. (2010): Chinese CEOs' leadership styles and firm performance. Journal of Asia Business Studies, 4(2), p. 73-79. doi:10.1108/ jabs.2010.4.2.73

Kazainé Ónodi, A. (2010): Értékválasztás, etikai dilemmák. Vezetéstudomány, 7-8., p. 33-42.

Kósa, G. (2013): Az ókori konfucianizmus. In: G. Kósa A. Várnai (eds.) (2013): Bölcselők az ókori Kínában. Budapest: ELTE Távol-keleti Intézet, p. 18-73.

Kósa, G. (2013): Az ókori taoizmus. In: G. Kósa, - A. Várnai (eds.) (2013): Bölcselök az ókori Kínában. Budapest: ELTE Távol-keleti Intézet, p. 93-144.

Kovács, G. (2014): The theoretical foundation of Buddhist management practices. Journal of Management Development, 33(8/9), p. 751-762. doi:10.1108/JMD-092013-0120

Kovács, G. (2016): A buddhista közgazdaságtan. Köz-gazdaság, 4. szám, p. 165-175.

KSH (2018): Hungarian Central Statistical Office. Retrieved 04 21, 2018, from http://www.ksh.hu/ docs/hun/xstadat/xstadat_eves/i_int044b.htm1?down $=160.8000030517578$
Lee, Y.-t. - Han, A.-g. - Byron, T. K. - Fan, H.-x. (2008): Daoist leadership: theory and application. In: C.-C. Chen, - Y.-T. Lee (eds.) (2018): Leadership and Management in China: Philosophies, Theories, and Practices. Cambridge: Cambridge University Press, p. 83-107.

Lin, L.-H. - Ho, Y.-L. (2009): Confucian dynamism, culture and ethical changes in Chinese societies - a comparative study of China, Taiwan, and Hong Kong. The International Journal of $\mathrm{Hu}-$ man Resource Management, 20(11), p. 2402-2417. doi:10.1080/09585190903239757

Morris, M. - Williams, K. - Leung, K. (1998): Conflict management style: Accounting for cross-national differences. Journal of International Business Studies, 29(4), p. 729-747. doi: 10.1057/palgrave. jibs. 8490050

Muyzenberg, L. (2014): The contribution of Buddhist wisdom to management development. Journal of Management Development, 33(8/9), p. 741-750. doi:10.1108/JMD-10-2013-0128

Nemcsicsné Zsóka, Á. (2006): A szervezeti kultúra szerepe a környezettudatos vállalati magatartásban. Vezetéstudomány, 9. sz., p. 27-38.

Ralston, D. - Egri, C. - Stewart, S. - Terpstra, R. - Yu, $K$. (1999): Doing business in the 21st century with the new generation of chinese managers: A study of generational shifts in work values in China. Journal of International Business Studies, 30(2), p. 415-427. doi:10.1057/palgrave.jibs.8490077

Rarick, C. A. (2009): The historical roots of Chinese cultural values and managarial practices. Journal of International Business Research, 8(2), p. 59-66.

Salát, G. (2009): A régi Kína története. Budapest: ELTE Konfuciusz Intézet

Salát, G. (2013): A teljhatalom ideológiája: a legizmus. In: G. Kósa, - A. Várnai (eds.) (2013): Bölcselők az ókori Kínában. Budapest: ELTE Távol-keleti Intézet, p. 145-171.

Sárvári, B. (2017): A kínai felzárkózás gazdaságpolitikai és geopolitikai vonatkozásai 1949-től 2007ig. Budapest: Corvinus University of Budapest, International Relations Multidisciplinary Doctoral School.

Tőkei, F. (1996): Kínai buddhista filozófia. Budapest: Balassi Kiadó

Wang, B. X. - Chee, H. (2011): Chinese Leadership. London: Palgrave MacMillan

Warner, M. (2010): In search of Confucian HRM: theory and practice in Greater China and beyond. The International Journal of Human Resource Management, 21(12), p. 2053-2078. doi: 10.1080/09585192.2010.509616

Wong, Y.-T. - Wong, S.-H. - Wong, Y.-W. (2010): A study of subordinate-supervisor guanxi in Chinese joint ventures. The International Journal of Human Resource Management, 21(12), p. 2142-2155. doi:10.108 $0 / 09585192.2010 .509621$

Wood, P. - Lamond, D. (2011): What would Confucius do? - Confucian ethics and self-regulation 
in management. Journal of Business Ethics(Vol. 102. No. 4.), p. 669-983. doi:10.1007/s10551-0110838-5

$X u, J$. (2009): The universal sentiment of Daoist morality. Frontiers of Philosophy in China, 4(4), p. 524536. doi:10.1007/s1 1466-009-0034-1

Yang, X.-h. - Peng, Y.-Q. - Lee, Y.-T. (2008): The Confucian and Mencian philosophy of benevolent leadership. In: C.-C. Chen, - Y.-T. Lee (eds.) (2008): Leadership and Management in China: Philoso- phies, Theories, and Practices. Cambridge: Cambridge University Press, p. 31-50.

Yao, $X$. (2000): An introduction to Confucianism. Cambridge: Cambride University Press

Zhang, Z.-x. - Chen, C.-c. - Liu, L. A. - Liu, X.-f. (2008): Chinese traditions and Western theories: influences on business leaders in China. In: C.-C. Chen - Y.-T. Lee (eds.) (2008): Leadership and Management in China: Philosophies, Theories, and Practices. Cambridge: Cambridge University Press, p. 239-271. 